\title{
Development of Rural Areas in Zones of Large Cities' Influence
}

\author{
Konstantin Getmantsev \\ Department of Organization and Planning of Local \\ Development \\ Kuban State University \\ Krasnodar, Russia \\ E-mail: kot34@mail.ru \\ Ekaterina Krylova \\ Department of Organization and Planning of Local \\ Development \\ Kuban State University \\ Krasnodar, Russia
}

\author{
Elena Ilyasova \\ Department of Organization and Planning of Local \\ Development \\ Kuban State University \\ Krasnodar, Russia \\ Evgeniya Atamas \\ Department of State and Municipal Administration \\ Kuban State University \\ Krasnodar, Russia \\ E-mail: eatamas@bk.ru
}

\begin{abstract}
The present article studies the issues of evaluating a large city's influence on socio-economic development processes in a rural area and the prospects for its independent development in the urban agglomeration. It analyses the changes in the system of rural settlement affected by the transport factor and circular migration of the local population to nearest cities.
\end{abstract}

Keywords-rural development; urban agglomeration; agglomeration development processes; urban and rural interaction

\section{INTRODUCTION}

One of the acute problems of urban agglomerations' development is the expansion of their influence on rural territories. The traditional boundaries between the city and the village are changing and rural territories gradually integrate into the urban economic space, which cannot but raise the issues of local economy, labor market and transformation of rural residents' lifestyles. These issues frequently pose significant challenges to the existence of rural territories; however, they can serve the purposes of social and economic development as well.

The article is aimed at studying the influence of cities on the development of rural territories and identifying the approach to framing the policy for rural territories development.

\section{The Krasnodar Urban Agglomeration AND RURAL AREAS COMPRISING IT}

In recent years, in the media of Krasnodar Krai there has been increased information on the Krasnodar urban agglomeration. Meanwhile, the given data is rather contradictory: the constituent elements of the agglomeration, its population and economy structure, etc. are presented differently. It can be explained by the fact that the concept of "the Krasnodar urban agglomeration" has not yet been enshrined in regional legislation. Therefore, it is a matter of priority to define the Krasnodar urban agglomeration, its structure and size.

The structure of the Krasnodar urban agglomeration can be described as follows [2]:

- the city of Krasnodar - the nucleus of the agglomeration;

- the Dinskoy District;

- the Krasnoarmeyskiy District;

- the Severskiy District;

- the Ust-Labinskiy District;

- the city of Goryachy Klyuch.

The city of Krasnodar, the nucleus of the agglomeration, is a multifunctional city, characterized by a multi-branch economy, substantial proportion of high-tech industries; considerable socio-cultural, scientific, technical and intellectual potential, and unique functions of national and international significance. [2].

The analysed rural district, the Severskiy District comprises the Krasnodar city agglomeration belt.

According to the official data, the Severskiy District is a medium-sized rural territory of Krasnodar Krai, located to the southwest of the region, on the left bank of the Kuban River, on the northwestern slope of the Greater Caucasus Mountain Range. The territory accounts for about 211 thousand hectares. The area is characterized by the moderately humid climate, with the annual mean rainfall of $700-800 \mathrm{~mm}$. The population of the area amounts to 117833 people [1]. 
Natural landscapes and attractive recreational spaces are areas of unique interest in the district.

When evaluating the role of the Severskiy District in the Krasnodar urban agglomeration, it is reasonable to assess its transport accessibility first.

The data on the distance and travel time from the settlements in the administrative centres of the Severskiy District to the city of Krasnodar was provided by the portal https://www.rudorogi.ru/ and is presented in "Table I" [7].

Studying the data we can conclude that most settlements of the municipal entities of the district meet the main criterion for the territories comprising the agglomeration accessibility by transport (travel time within 1.5 hours).

However, due to the rugged landscape of the Severskiy District (flat terrain, piedmont, mountain areas, extending to the Caucasus Mountain Ridge) transport communication between individual settlements and the nucleus of the agglomeration is impeded [8].

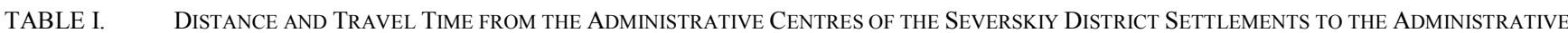
BORDER OF THE City OF KRASNODAR (AT THE AVERAGE SPEED OF 60 KM/H)

\begin{tabular}{|c|c|c|c|}
\hline Inhabited localities & Distance, $\mathbf{k m}$ & Average travel time, $\min$ & Available means of transport \\
\hline $\begin{array}{l}\text { Afipskoye urban settlement (Afipskiy } \\
\text { urban-type settlement) }\end{array}$ & 29 & 32 & Automobile, bus, railway \\
\hline $\begin{array}{l}\text { Ilskoye urban settlement (Ilskiy urban- } \\
\text { type settlement) }\end{array}$ & 52 & 58 & Automobile, bus, railway \\
\hline $\begin{array}{l}\text { Chernomorskoye urban settlement } \\
\text { (Chernomorskiy urban-type settlement) }\end{array}$ & 67 & $1 \mathrm{~h} .03 \mathrm{~min}$. & Automobile, bus, railway \\
\hline $\begin{array}{l}\text { Azovskoye rural settlement (Azovskaya } \\
\text { stanitsa) }\end{array}$ & 48 & 57 & Automobile, bus \\
\hline $\begin{array}{l}\text { Grigor'yevskoye rural } \\
\text { (Grigor'yevskaya stanitsa) }\end{array}$ & 85 & 1 h. $52 \mathrm{~min}$. & Automobile, bus \\
\hline $\begin{array}{ll}\begin{array}{l}\text { Kaluzhskoye rural } \\
\text { (Kaluzhskaya stanitsa) }\end{array} & \text { settlement } \\
\end{array}$ & 54 & $1 \mathrm{~h} .2 \mathrm{~min}$. & Automobile, bus \\
\hline $\begin{array}{l}\text { L'vovskoye rural settlement (L'vovskoye } \\
\text { village) }\end{array}$ & 49 & 51 & Automobile, bus \\
\hline $\begin{array}{l}\text { Aleksandrovskoye rural } \\
\text { (Aleksandrovskiy khutor) }\end{array}$ & 67 & 1 h. $12 \mathrm{~min}$. & Automobile, bus \\
\hline $\begin{array}{l}\text { Mikhaylovskoye rural } \\
\text { (Mikhailovskiy settlement) }\end{array}$ & 68 & 1 h. $27 \mathrm{~min}$. & Automobile, bus \\
\hline $\begin{array}{lcc}\text { Novodmitriyevskoye rural } & \text { settlement } \\
\text { (Novodmitrievskaya stanitsa) } & \\
\end{array}$ & 28 & 24 & Automobile, bus \\
\hline $\begin{array}{l}\text { Severskoye rural settlement (Severskaya } \\
\text { stanitsa) }\end{array}$ & 37 & 32 & Automobile, bus, railway \\
\hline $\begin{array}{ll}\text { Smolenskoye rural } & \text { settlement } \\
\text { (Smolenskaya stanitsa) } & \end{array}$ & 32.6 & 46 & Automobile, bus \\
\hline $\begin{array}{l}\text { Shabanovskoe rural } \\
\text { (Shabanovskoe village) }\end{array}$ & 82 & 1 h. $57 \mathrm{~min}$. & Automobile, bus \\
\hline
\end{tabular}

The most remote inhabited settlements include the Plancheskaya Shchel settlement - $112 \mathrm{~km}$ (3 hours 17 minutes of travel time); the Tkhamakha village - $148 \mathrm{~km}(3$ hours 47 minutes of travel time); the Mirnyy settlement - 117 $\mathrm{km}$ (3 hours 25 minutes of travel time); the Ubinskaya stanitsa - $142 \mathrm{~km}$ (3 hours 12 minutes of travel time); the Derbentskaya stanitsa - $157 \mathrm{~km}$ (over 4 hours of travel time) ("Table I"). [7].
III. IDENTIFYING ZONES OF URBAN AGGLOMERATION INFLUENCE ON ECONOMIC DEVELOPMENT OF THE RURAL

\section{AREA}

Taking into account the described conditions, it can hardly be said that the Krasnodar urban agglomeration incorporates the whole Severskiy District and influences it as much as its other constituent elements. Thus, the territories of the region are involved in the agglomeration processes to a greater or lesser extent. 
habitability of the territory and the opportunities of convenient transportation. [3].

A core of employment is industrial and agricultural production, research and training centres, administration, etc. i.e. a place to concentrate people for the production of material and nonmaterial values, management, personal contacts and communication. The population is the main productive force of society, while its settlement is the arrangement of productive forces across territories. Nevertheless, for productive forces to function effectively, the space has to be specially organized. Therefore, it is exactly the settlement system, which has a regulatory role in the territorial structure of productive forces [3].

As a part of the Krasnodar urban agglomeration, the Severskiy District, is inevitably faced with changes in the settlement system. Table 2 provides an overview of these changes [32]. In order to illustrate them more clearly, the data is presented in three periods over the past 20 years.

Some of the trends require special attention.

First, there is a positive dynamics in the number of large inhabited settlements in general and in the administrative centres of rural and urban settlements of the Severskiy District in particular. Most of the rural centres increased their population over the past 20 years. The largest population growth was recorded in the Afipskiy urban-type settlement, the Ilskiy urban-type settlement and the Severskaya stanitsa. The negative trend is characteristic only of the Alexandrovskiy khutor. 15 people - is the official number of its residents, which reduced to 8 people in 2018 [6].

Simultaneously, the population decrease is observed in small inhabited settlements, especially in villages in the periphery.

The population is also declining in the Tkhamakha village, the Naumenkov khutor, the Oasis khutor, the Shuvayev khutor, the Anan'yevskiy khutor, the Peschanyy khutor, the Novoivanovskiy khutor, the Krasnyy khutor, the Chibiy settlement, the Stavropol'skaya stanitsa, the Kipyachiy khutor, and the Kosharskiy khutor. These inhabited settlements used to be workers' settlements, thus the termination of operations or reduced volumes of work resulted in the population decrease. For instance, when logging enterprises were closed in Chibiy in 1998, the settlement lost $97 \%$ of its population. Today, the official population there amounts to 30 people, with only 4 residents living in the settlement permanently [4] ("Table II").

\section{Changes IN THE SETTLEMENT SyStEM AND \\ DEMOGRAPHIC PROCESSES OF THE RURAL AREA INFLUENCED BY THE AGGLOMERATION}

One of the most important outcomes of rural areas being influenced by the agglomeration is changes in their settlement systems.

In a broad sense, a settlement system is the system for locating the population and populated areas across the country (region). The settlement location is always preconditioned by three factors: cores of employment, 
TABLE II. Changes IN THE SETTLEMENT System OF THE SEVERSKIY District

\begin{tabular}{|c|c|c|c|}
\hline \multirow[t]{2}{*}{ Inhabited localities } & \multicolumn{3}{|c|}{ Years } \\
\hline & 1996 & 2006 & 2016 \\
\hline \multicolumn{4}{|c|}{ Afipskoye urban settlement } \\
\hline Afipskiy urban-type settlement & 18412 & 19324 & 20114 \\
\hline Vodokachka khutor & 287 & 227 & 129 \\
\hline Vostochnyy khutor & 517 & 449 & 340 \\
\hline Kovalenko khutor & 387 & 412 & 641 \\
\hline Kosharskiy khutor & 78 & 22 & 13 \\
\hline Neftekachka settlement & 114 & 82 & 56 \\
\hline \multicolumn{4}{|c|}{ Ilskoye urban settlement } \\
\hline Ilskiy urban-type settlement & 16805 & 18715 & 24944 \\
\hline Derbentskoye village & 1022 & 712 & 634 \\
\hline \multicolumn{4}{|c|}{ Chernomorskoye urban settlement } \\
\hline Chernomorskiy settlement & 6265 & 6912 & 7205 \\
\hline Oktyabrskiy settlement & 914 & 1372 & 1857 \\
\hline Karskiy khutor & 218 & 243 & 214 \\
\hline Novopetrovskiy settlement & 1026 & 815 & 419 \\
\hline Vesolyy khutor & 508 & 412 & 316 \\
\hline Kipyachiy khutor & 318 & 257 & 127 \\
\hline Sputnik settlement & 128 & 522 & 712 \\
\hline \multicolumn{4}{|c|}{ Azovskoye rural settlement } \\
\hline Azovskaya stanitsa & 2308 & 2714 & 3874 \\
\hline Ubinskaya stanitsa & 307 & 511 & 452 \\
\hline \multicolumn{4}{|c|}{ Grigor'yevskoye rural settlement } \\
\hline Grigor'yevskaya stanitsa & 963 & 1087 & 1247 \\
\hline Stavropol'skaya stanitsa & 1352 & 1105 & 815 \\
\hline \multicolumn{4}{|c|}{ Kaluzhskoye rural settlement } \\
\hline Kaluzhskaya stanitsa & 1678 & 1815 & 1925 \\
\hline Chibiy settlement & 214 & 52 & 30 \\
\hline \multicolumn{4}{|c|}{ L'vovskoye rural settlement } \\
\hline L'vovskoye village & 4247 & 4732 & 5171 \\
\hline Krasnyy khutor & 255 & 211 & 179 \\
\hline Novoivanovskiy khutor & 289 & 265 & 210 \\
\hline Peschanyy khutor & 315 & 187 & 65 \\
\hline Stefanovskiy khutor & 285 & 244 & 236 \\
\hline \multicolumn{4}{|c|}{ Aleksandrovskoye rural settlement } \\
\hline Mikhailovskoye village & 2057 & 1862 & 1775 \\
\hline Alexandrovskiy khutor & 87 & 34 & 15 \\
\hline Anan'yevskiy khutor & 627 & 415 & 325 \\
\hline \multicolumn{4}{|c|}{ Novodmitriyevskoye rural settlement } \\
\hline Novodmitrievskaya stanitsa & 4283 & 5472 & 5718 \\
\hline Shuvayev khutor & 1072 & 825 & 512 \\
\hline Oasis khutor & 612 & 583 & 487 \\
\hline Novyy khutor & 286 & 207 & 377 \\
\hline \multicolumn{4}{|c|}{ Severskoye rural settlement } \\
\hline Severskay stanitsa & 21568 & 22085 & 24812 \\
\hline Bonchkovskiy khutor & 638 & 758 & 816 \\
\hline Bondarenko khutor & 415 & 388 & 311 \\
\hline Volikov khutor & 127 & 95 & 87 \\
\hline Naumenkov khutor & 392 & 312 & 247 \\
\hline Novoalekseevskiy khutor & 128 & 214 & 319 \\
\hline Svobodnyy khutor & 94 & 107 & 112 \\
\hline 8 March settlement & 393 & 358 & 415 \\
\hline Predgornyy khutor & 316 & 385 & 317 \\
\hline \multicolumn{4}{|c|}{ Smolenskoye rural settlement } \\
\hline Krepostnaya stanitsa & 3107 & 3248 & 3057 \\
\hline Smolenskaya stanitsa & 3987 & 3875 & 4218 \\
\hline Mirnyy settlement & 482 & 468 & 412 \\
\hline Plancheskaya Shchel settlement & 312 & 344 & 328 \\
\hline \multicolumn{4}{|c|}{ Shabanovskoe rural settlement } \\
\hline Shabanovskoe village & 422 & 458 & 412 \\
\hline Tkhamakha village & 397 & 355 & 308 \\
\hline
\end{tabular}

The following settlements located along the A-146 federal highway demonstrate a positive trend: the Oktyabrskiy settlement, the Chernomorskiy settlement, the
Ilskiy urban-type settlement, the Severskaya stanitsa, the Afipskiy urban-type settlement, the 8 Marta settlement, the 
the centre and from the centre to the cities. However, this process is only partially characteristic of the Severskiy District: the population do not move to the Severskaya stanitsa, but directly to several large settlements located on the Krasnodar-Novorossiysk federal highway. Meanwhile, the settlements that are geographically closer to the city of Krasnodar grow to a greater extent. This shows that the population does not leave the Severskiy District, but relocates to those settlements more convenient for living and closer to the city, thus shaping "rural" residential areas of the city of Krasnodar.

Another trend is a positive net migration. According to the data of the Severskiy District administration, the population of the district has been growing, including due to the influx of new residents into the district (See "Table III"). [4].

should be mentioned that all the changes in the settlement system of the Severskiy District prove a wellknown fact: the rural population moves from the periphery to

TABLE III. POPUlATION DYNAMICS IN THE SEVERSKIY DisTRICT

\begin{tabular}{|l|l|l|l|l|l|l|}
\hline \multicolumn{1}{|c|}{ Indicator } & \multicolumn{1}{|c|}{$\mathbf{2 0 1 1}$} & \multicolumn{1}{|c|}{$\mathbf{2 0 1 2}$} & \multicolumn{1}{|c|}{$\mathbf{2 0 1 3}$} & $\mathbf{2 0 1 4}$ & $\mathbf{2 0 1 5}$ \\
\hline $\begin{array}{l}\text { Standard residential } \\
\text { population, pers. }\end{array}$ & 113094 & 114394 & 115149 & 116261 & 117073 \\
\hline $\begin{array}{l}\text { Natural population growth } \\
(+) / \text { decline (-), pers. }\end{array}$ & -278 & -314 & -87 & -104 & -117 \\
\hline $\begin{array}{l}\text { Migration gain (+)/ loss (-) } \\
\text { of the population, pers. }\end{array}$ & +827 & +986 & +668 & +1008 & -218 \\
\hline
\end{tabular}

The comparison of the figures of natural and migration population growth demonstrates that the $2 \%$ growth is predominantly due to migration influx of the population rather than to its natural increase.

Unfortunately, the data on migrants was not available; however, as far as the authors are concerned, most of them are concentrated in three inhabited settlements of the region: the Afipskiy urban-type settlement, the Ilskiy urban-type settlement and the Severskaya station.

It can also be assumed that urban residents themselves contribute to migration flows at least in two possible ways. The first way is connected with the practice of downshifting, when urban residents, tired of hectic city life move to quieter and cheaper areas. The second way is related to making a conscious choice in favour of a village life, mostly for economic reasons.

\section{CONCLUSION}

To conclude, it can be emphasized that the territories of the Severskiy District respond differently to the proximity of Krasnodar and are engaged into the activity of the agglomeration to varying degrees. Therefore, some territories integrate into the agglomeration's life and find new development opportunities in being involved into the city's zone of influence, while others fail sustain their capacity for development and maintain their population and economies. In a part of the areas, the population is on the verge of vanishing, which cannot be helped even by their location in proximity to large cities. Moreover, all processes take place randomly, influenced by external factors and are practically uncontrolled by local administrations.

\section{REFERENCES}

[1] Krasnodar. Wikipedia free encyclopaedia. Available at: https://ru.wikipedia.org/wiki/krdn

[2] Lavrova T.G. Urban agglomeration of Krasnodar: development and management // The contours of global transformations: Politics, Economics, Law. 2015. No. 5. Pp. 80-89.

[3] Leksin V.N. Urban agglomerations and the settlement system: hopes and fears. Moscow. Infra-M. 2011. 267 p.

[4] Migration in the Severskiy District of Krasnodar Krai. Materials of the migration centre of the Severskiy district of Krasnodar Krai. Available at: http://www.sevadm.ru/2013/10/29/migracija.html.

[5] The website of the Severskiy District of Krasnodar Krai. Available at: http://www.sevadm.ru/.

[6] Districts and cities of Krasnodar Krai. Statistical Compendium. Krasnodar. Rosstat. 2018. 311 p.

[7] Calculating the distance between cities. "RUdorogi". Available at: https://www.rudorogi.ru/

[8] Severskiy District. Wikipedia free encyclopaedia Available at https://ru.wikipedia.org/wiki/\%D0\%A1\%D0\%B5\%D0\%B2\%D0\%B5 $\% \mathrm{D} 1 \% 80 \% \mathrm{D} 1 \% 81 \% \mathrm{D} 0 \% \mathrm{BA} \% \mathrm{D} 0 \% \mathrm{~B} 8 \% \mathrm{D} 0 \% \mathrm{~B} 9+\% \mathrm{D} 1 \% 80 \% \mathrm{D} 0 \% \mathrm{~B}$ $0 \% \mathrm{D} 0 \% \mathrm{~B} 9 \% \mathrm{D} 0 \% \mathrm{BE} \% \mathrm{D} 0 \% \mathrm{BD}$ 